\title{
Varicella-zoster virus DNA in the oesophageal myenteric plexus in achalasia
}

\author{
C S Robertson, B A B Martin, M Atkinson
}

\begin{abstract}
In a search for past or present infection with herpes viruses, serum antibody titres to herpes simplex type 1 virus, cytomegalovirus, and varicella-zoster virus were measured by complement fixation test in 58 patients with achalasia. Serum was also taken from 40 age and sex matched patients without oesophageal symptoms who formed a control group. All titres were low, and those for herpes simplex type 1 virus and cytomegalovirus did not differ in the achalasia patients and the controls. However, the incidence of varicella-zoster virus antibodies was significantly greater in the achalasia than in the control group $(\mathbf{p}<0.05)$. Using oesophageal tissue containing myenteric plexus removed at the time of cardiomyotomy in nine patients with achalasia, in situ DNA hybridisation showed evidence of varicella-zoster virus in three, but all were negative for the other two viruses. No positive results were obtained for herpes simplex type 1 virus, cytomegalovirus, or varicella-zoster virus in oesophageal tissue from 20 patients undergoing oesophageal resection for diseases other than achalasia. The incidence of positivity for varicella-zoster virus was significantly increased in the achalasia group compared with the controls $(\mathbf{p}<0 \cdot 02)$. The findings indicate that varicellazoster virus DNA may persist in the oesophageal myenteric plexus in some patients with achalasia and raise the possibility that this virus is of aetiological importance in achalasia. (Gut 1993; 34: 299-302)
\end{abstract}

Although the cause of achalasia of the cardia remains obscure, there is convincing evidence that the oesophageal motor disorder results from damage to the oesophageal myenteric plexus with ganglion cell depletion. ${ }^{12}$ An intriguing feature of the disease is its localisation to the oesophagus without affecting the rest of the gut. The oesophagus is unique in being the only part of the alimentary tract lined by squamous epithelium and the known predilection of the herpes class of viruses for squamous rather than columnar epithelium is consonant with the oesophageal mucosal involvement reported in varicella, ${ }^{3+}$ herpes simplex, ${ }^{56}$ and cytomegalovirus infections. ${ }^{78}$ These viruses are neurotropic and the varicella-zoster virus has been shown to persist in posterior nerve root ganglia ${ }^{9}$ where it may remain dormant for years until reactivated in herpes zoster. This led us to the hypothesis that the ganglion cell loss in achalasia may be the result of persistent herpes virus infection in the oesophageal myenteric plexus.

This study aimed to test this hypothesis, firstly by examining the serum for antibodies to herpes simplex type 1 virus, varicella-zoster virus, and cytomegalovirus and secondly by in situ hybridisation studies on resected oesophageal tissue using DNA probes to these viruses.

\section{Methods}

\section{SEROLOGICAL STUDIES}

Sera were obtained from 58 patients (26 men; median age 48 years; range 19-90 years) with established achalasia of the cardia, and 40 age and sex matched controls without oesophageal disorders (23 men; median age 57 years; range 15-76 years) recruited from the gastroenterology clinic. Control subjects were matched to within 5 years of the patients' age.

Serum antibody titres. Serum antibody titres to herpes simplex type 1 virus, cytomegalovirus, and varicella-zoster virus were determined by a modification of the complement fixation test described by Bradstreet and Taylor. ${ }^{10}$

\section{IN SITU HYBRIDISATION STUDIES}

Specimens of oesophageal muscle were obtained from nine patients with proved achalasia (five men; median age 32 years; range $14-45$ years) and from 20 control patients $(10$ men; median age 59 years; range 5-75 years), 17 of whom had undergone oesophagectomy for malignant disease and three of whom were cadaveric renal transplant donors.

\section{Fresh tissue}

All specimens from the achalasia patients and five from the control subjects were collected fresh at the time of operation. The tissue was orientated transversely under a dissecting microscope by a consultant neuropathologist before snap freezing in liquid nitrogen and isopentane. The tissue blocks were stored at $-196^{\circ} \mathrm{C}$ Cryostat sections $(5 \mu \mathrm{m})$ were subsequently cut and the slides were stored at $-70^{\circ} \mathrm{C}$ until use. Every fourth slide was stained with haematoxylin and eosin to confirm the correct orientation of the tissue. 
Fixed Tissue

Oesophageal specimens from 15 patients who had undergone subtotal oesophagectomy for cancer were also used as controls. After being fixed in buffered formalin and embedded in paraffin wax in the usual way, $5 \mu \mathrm{m}$ sections were cut on to poly-l-lysine coated slides to improve tissue adhesion. Tissues known to be infected by herpes viruses were used as positive controls (sections of a chickenpox vesicle, renal tissue infected with cytomegalovirus, and brain infected with herpes simplex virus).

\section{DNA HYBRIDISATION}

\section{Preparation of DNA probes}

The following DNAs were used: the HindIII BL fragment, cloned in pTR262, of the genome of a varicella-zoster virus strain obtained from a chickenpox patient; genome DNA of herpes simplex type 1 virus strain Troisbel; the EcoRI EK fragment of the genome of herpes simplex type 1 virus strain Troisbel; the HindIII F fragment of the genome of cytomegalovirus (Towne strain); and pAT153, a plasmid probe used to detect bacterial contamination. The DNAs were labelled with biotin using biotindUTP or biotin dLTP by nick translation (BRL, Paisley) and used for hybridisation of slides at concentrations of about $2-3 \mu \mathrm{g} / \mathrm{ml}$. Probes were tested for efficacy by hybridisation to control DNA dot blots prepared by loading samples on to a nitrocellulose filter using a Bio-Dot apparatus (Bio-Rad Instruments, Watford); and also by hybridisation to Cytospin preparations of infected and uninfected cells on glass slides coated with aminopropyltriethoxysilane (APES) by immersing in $2 \%$ Apes in acetone, rinsing, and allowing to dry.

\section{Hybridisation of dot blots}

The filter was wetted in $0.2 \%$ bovine serum albumin, $0 \cdot 2 \%$ Ficoll, $0 \cdot 2 \%$ polyvinylpyrrolidone $(10 \times$ Denhardt's solution $)$ in $0.6 \mathrm{M} \mathrm{NaCl}$, $0.06 \mathrm{M}$ sodium citrate $(4 \times \mathrm{SSC})$, and shaken at room temperature for 2 hours. It was then sealed in a polythene bag with $45 \%$ formamide, $5 \times$ SSC, $1 \times$ Denhardt's solution, $0 \cdot 1 \%$ sodium dodecylsulphate (SDS), $1 \mathrm{mM}$ EDTA, and 100 $\mu \mathrm{g} / \mathrm{ml}$ denatured salmon sperm DNA containing probe and was incubated at $42-45^{\circ} \mathrm{C}$ overnight. Probe consisted of about $0 \cdot 1 \mu \mathrm{g} / \mathrm{ml}$ biotinylated DNA. The probe and the filter were removed from the bag and the filter was washed successively in $2 \times \mathrm{SSC}, 0 \cdot 1 \%$ SDS and $0 \cdot 2 \times \mathrm{SSC}, 0 \cdot 1 \%$ SDS twice each for 5 minutes at room temperature, then in $0 \cdot 16 \times \mathrm{SSC}, 0 \cdot 1 \%$ SDS twice for 15 minutes at $50^{\circ} \mathrm{C}$. Finally filters were rinsed in $2 \times$ SSC. The filter was incubated with a streptavidin-alkaline phosphatase conjugate (using the BluGENE kit from Bethesda Research Laboratories, Paisley).

Colour development was achieved by incubating the filters in a solution of buffer $(0 \cdot 1 \mathrm{M}$ Tris-HCl; $\mathrm{pH} 7 \cdot 5), 0 \cdot 1 \mathrm{M} \mathrm{NaCl}, 2 \mathrm{mM} \mathrm{Mg} \mathrm{Cl}_{2}$, $3 \%$ bovine serum albumin) containing $75 \mathrm{mg} / \mathrm{ml}$ of nitro blue tetrazolium in $70 \%$ dimethyl- formamide, and $50 \mathrm{mg} / \mathrm{ml}$ of 5-bromo-4-chloro-5 indolyl phosphate in dimethylformamide.

\section{Pretreatment and dehybridisation of fresh tissue}

Cryostat sections were thawed at room temperature and processed according to a standard method" except that they were processed on untreated glass slides, and paraformaldehyde was prepared in Dulbecco A solution. ${ }^{12}$

After pretreatment the cryostat sections were immersed in $2 \times$ SSC $50 \%$ formamide for 10 minutes at room temperature and prehybridised at room temperature with hybridisation buffer not containing probes for 20 minutes.

\section{Pretreatment of fixed tissue}

Sections were dewaxed and were then hydrated by sequential washes of twice for 1 minute in graded ethanol $(95 \%, 80 \%, 60 \%$, and $30 \%)$ followed by a brief wash in distilled water and 1 minute in Dulbecco A solution. The specimens were then processed according to a method modified from ${ }^{13}$ that considerably shortened the preparation time. No prehybridisation was necessary for paraffin wax embedded specimens. Before the hybridisation mixture was applied, the slides were dipped briefly into $2 \times$ SSC and the excess liquid was wiped away.

\section{In situ hybridisation procedure}

Slides were air dried before in situ hybridisation with 15-20 $\mu$ l of probe solution, consisting of biotinylated DNA in $40 \%$ formamide $4 \times$ SCC, $1 \times$ Denhardt's solution, $0.2 \mathrm{mg} / \mathrm{ml}$ denatured salmon sperm DNA. After pipetting the hybridisation mixture onto the tissue sections, the edges of the siliconised glass coverslips were sealed with rubber solution and allowed to air dry. Simultaneous denaturation of cellular DNA in the tissue sections and probes was achieved by heating the slides at $80-85^{\circ} \mathrm{C}$ for 10 minutes and they were then incubated for 16-18 hours at $38.5^{\circ} \mathrm{C}$ in a humidified box. The slides were then immersed in $2 \times$ SSC and the rubber seal was carefully peeled off. The slides were washed sequentially in SSC and buffers I and II before detection of hybridisation signals.

\section{Detection of hybridisation signals}

Biotinylated DNA was detected using a streptavidin-alkaline phosphatase system (BluGENE) in a humidified box and incubation for 30 minutes to 4 hours in the dark, monitoring colour development at frequent intervals. After development the colour reaction was stopped and counterstaining with $2 \%$ methyl green and mounted in glycerol $(20 \%$ in - Dulbecco A solution) was used.

\section{STATISTICAL ANALYSIS}

Analysis was by Fisher's exact test with a value of p less than 0.05 taken to denote statistical significance.

Informed consent was obtained for operative tissue samples to be obtained and the study was 
Positivity of complement fixation tests for herpes simplex type 1 virus, cytomegalovirus, and varicella-zoster virus in achalasia patients and controls

\begin{tabular}{lllllllll}
\hline & \multicolumn{3}{l}{$\begin{array}{l}\text { Achalasia } \\
(n=58)\end{array}$} & & & & \multicolumn{2}{l}{$\begin{array}{l}\text { Controls } \\
(n=40)\end{array}$} \\
\cline { 2 - 4 } \cline { 6 - 8 } Titres & 16 & 32 & 64 & & 16 & 32 & 64 \\
\hline Herpes simplex type 1 virus & 20 & 3 & - & & 12 & 1 & - \\
Cytomegalovirus & 17 & - & 2 & & 10 & 1 & - \\
Varicella-zoster virus & 14 & 2 & - & & - & - & 1 \\
\hline
\end{tabular}

approved by the Nottingham Hospital Ethical Committee.

\section{Results}

\section{SEROLOGICAL STUDIES}

Viral serology was positive in 37 of the 58 patients $(63.8 \%)$ with achalasia (23 herpes simplex type 1 virus; 19 cytomegalovirus; 16 varicella-zoster virus and in 19 of the $40(47 \cdot 5 \%)$ control sera (13 herpes simplex type 1 virus; 11 cytomegalovirus; one varicella-zoster virus). All the titres were low, however, and are shown in the Table. When patient and control groups

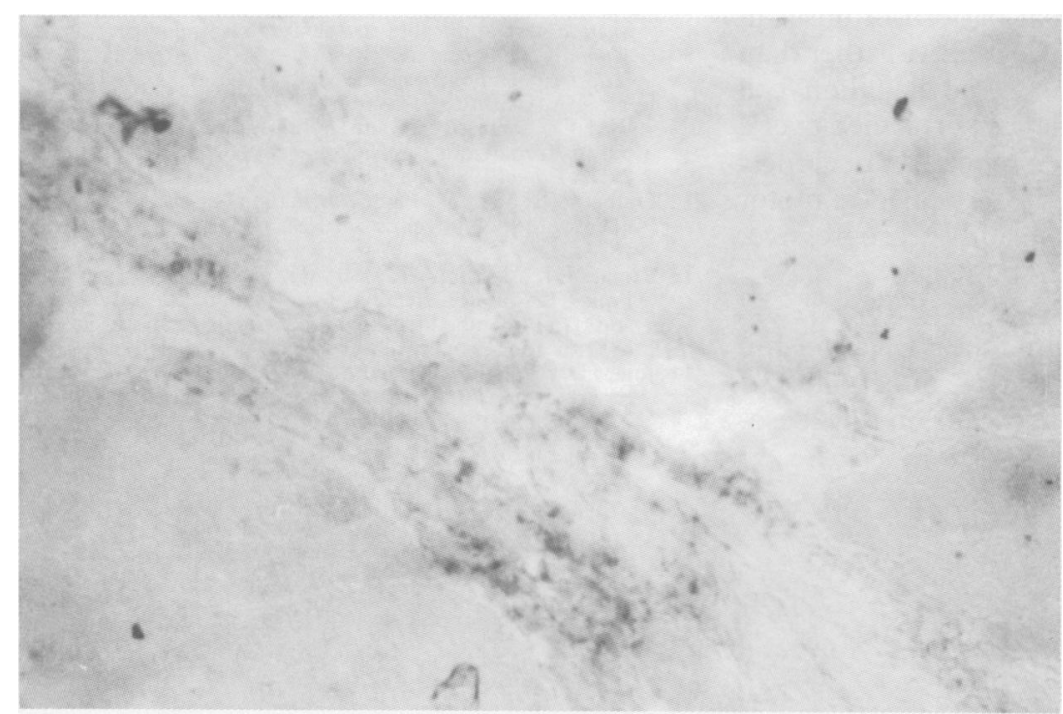

Figure 1: Transverse section through the myenteric plexus in a tissue sample from a patient with achalasia showing positive staining for varicella-zoster virus.

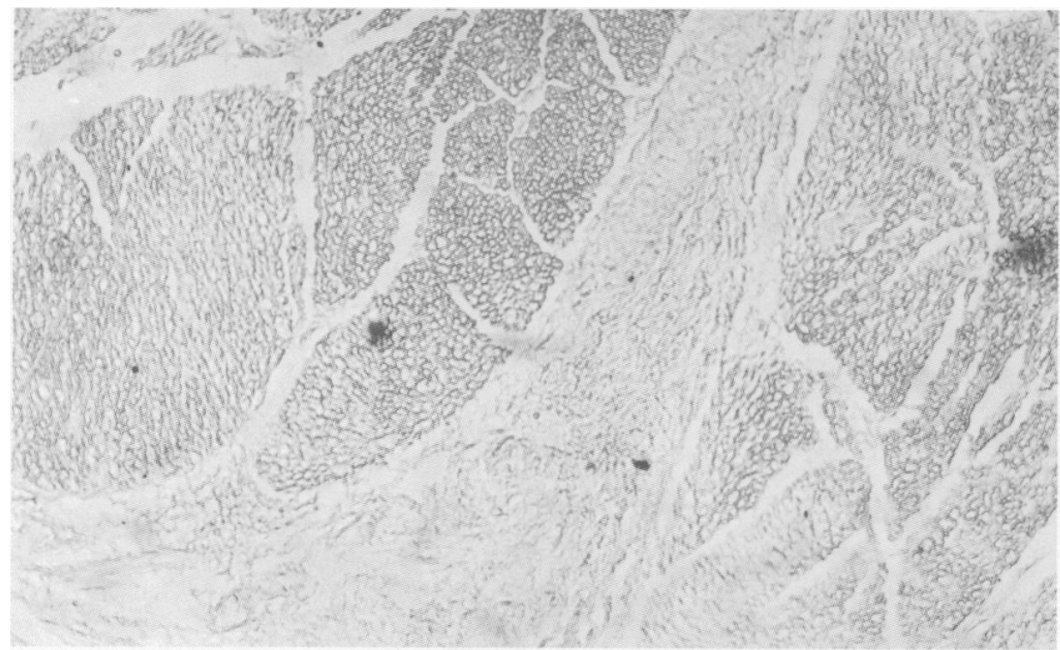

Figure 2: Transverse section through the myenteric plexus in a tissue sample from a patient with achalasia showing negative staining for herpes simplex type 1 virus. This sample had shown positive staining for varicella-zoster virus. were compared for each type of virus, a statistically significant difference was seen only for varicella-zoster virus $\left(\chi^{2}=8 \cdot 7148 ; p\right.$ less than 0.05; Fisher's exact test and Yates's correction), for which a positive titre was obtained in sera from 16 of 58 patients with achalasia compared with one of 40 controls.

\section{DETECTION OF DNA IN TISSUE SECTIONS}

Oesophageal tissue sections from nine patients with achalasia and from 20 controls were hybridised with varicella-zoster virus, herpes simplex type 1 virus, cytomegalovirus, and pAT153 probes. After staining, a clearly positive hybridisation signal was detected with varicella-zoster virus in tissue from three patients' with achalasia (Fig 1) but in none of the 20 control samples. This difference was clearly significant, with a $p$ value of 0.02 by Fisher's exact test. Positivity did not correlate with the age of the patient or the duration of disease. No clearly positive hybridisation signal was detected in any of the specimens (patients or controls), with cytomegalovirus, herpes simplex type 1 virus, or pAT 153 probes (Fig 2).

\section{Discussion}

The three herpes viruses chosen for this study are all recognised as causing oesophageal ulceration but seldom affect the columnar epithelium of the remainder of the gut. Herpes simplex type 1 virus and varicella-zoster virus are known to be neurotropic, and cytomegalovirus infections of the central nervous system have been reported hence all three seemed possible causes of damage to the oesophageal myenteric plexus.

The serum antibody titres to all three viruses were generally low and only in the case of varicella-zoster virus were they significantly greater in patients with achalasia than in the controls. This suggests that these patients have had greater exposure to varicella in the past. In Britain, varicella is prevalent in childhood, yet in only one of 40 control patients was antibody detected that might point to past attacks of greater severity in the patients with achalasia than in the control group. We know of no clinical evidence, however, to support this contention. Our studies did not encompass other viruses but an increased antibody titre against measles virus has been reported from Cardiff. ${ }^{14}$

The DNA probes used in this study are highly specific for herpes simplex type 1 virus, varicellazoster virus, and cytomegalovirus respectively and in this context the demonstration of varicella-zoster virus material in the oesophageal wall in three of nine patients with achalasia is clearly significant. It suggests that the virus may persist in the oesophageal wall for many years after an attack of varicella but only in some of those patients who have developed achalasia. Varicella-zoster virus positivity did not correlate with either age or disease duration and unfortunately few subjects could recall if and when they had had varicella.

If varicella-zoster virus is of aetiological importance in achalasia, an explanation must be sought for why only three of nine patients with 
this disorder were varicella-zoster virus positive. We do not know how much viral DNA is needed to give a positive signal and it could be that the six varicella-zoster virus negative achalasia patients had this material present in amounts too small to be detectable by the method employed. Alternatively, the varicella-zoster virus may have disappeared from these patients and, since we did not obtain myenteric plexus ganglion cell counts, we were unable to correlate varicellazoster virus positivity with severity of myenteric plexus damage. Positivity may be patchily distributed, as has been reported in the trigeminal ganglia, ${ }^{9}$ and this would result in a sampling error, particularly since the tissue samples removed at the time of cardiomyotomy were relatively small in size. A third possibility is that viruses other than varicella-zoster virus may cause oesophageal myenteric plexus damage, but our findings indicate that herpes simplex type 1 virus and cytomegalovirus are unlikely to be involved.

Varicella-zoster virus is known to be neutrotropic but may lie dormant in the tissues for many years before becoming reactivated as in herpes zoster. Whether this could be the case in the oesophageal myenteric plexus is uncertain but the much more gradual pattern of onset in achalasia indicates slowly progressive rather than explosive neural damage. Serial ganglion cell counts in the myenteric plexus performed over a period of time have not been reported but clinical observation suggests that the oesophageal motor disturbance is often steadily progressive, implying progressive neural damage.

In summary, both the serum antibody and DNA probe studies point to a relationship between varicella-zoster virus infection and achalasia. Varicella lesions occur in the oeso- phageal mucosa, which would give the virus ready access to the oesophageal myenteric plexus, but this route would seem more probable if the myenteric plexus elsewhere in the gut were to be shown to be negative for varicella-zoster virus. Our findings suggest further studies should be undertaken to confirm and delineate the extent of varicella-zoster virus involvement of neural tissue in achalasia of the cardia.

1 Casella RR, Brown AL Jr, Sayre GP, Ellis FH Jr. Achalasia of the esophagus: pathologic and etiologic considerations. Ann Surg 1964; 160: 474-86.

2 Misiewicz JJ, Waller SL, Anthony PP, Gummer JWP. Achalasia of the cardia: pharmacology and histopathology of isolated cardiac sphincteric muscle from patients with and without achalasia. $Q \mathcal{F}$ Med 1969; 38: 17-30.

3 Johnson HN. Visceral lesions associated with varicella. Arch Pathol 1940; 30: 292-307.

4 Gill RA, Gebhard RL, Dozeman RL, Sumner HW. Shingles esophagitis - endoscopic diagnosis in two patients. Gastrointest Endosc 1984; 30: 26-7.

5 Springer DJ, Da Costa LR, Beck IT. A syndrome of acute self limiting ulcerative esophagitis in young adults probabl due to herpes simplex virus. Dig Dis Sci 1979; 24: 535-9.

6 Agha FP, Lee HH, Nostrant TT. Herpetic esophagitis: a diagnostic challenge in immunocompromised patients. Am $\mathcal{f}$ Gastroenterol 1986; 81: 246-53.

7 Toghill PJ, McGuaghey M. Cytomegalovirus oesophagitis. BMF 1972; ii: 294.

8 Villar LA, Massanari RM, Mitros FA. Cytomegalovirus infection with acute erosive esophagitis. Am $\mathcal{F}$ Med 1984; 76: 924-8.

9 Hyman RW, Ecker JR, Tenser RB. Varicella-zoster virus RNA in human trigeminal ganglia. Lancet 1983; ii: 814-6.

10 Bradstreet CMP, Taylor CED. Technique of complement fixation test applicable to the diagnosis of virus disease. Monthly Bulletin of the Ministry of Health and the Public Monthly Bulletin of the Ministry of Health

11 Lewis FA, Griffiths S, Dunnicliff R, Wells M, Dudding N, Bird CC. Sensitive in-situ hybridisation technique using biotin-streptavidin polyalkaline phosphatase complex. f Clin Pathol 1987; 40: 163-6.

12 Dulbecco $R$, Vogt $M$. Plaque formation and isolation of pure lines with poliomyelitis viruses. $\mathcal{F}$ Exp Med 1954; 99 . 167-82.

13 Brigati DJ, Myerson D, Leary JJ, Spazholz B, Travis SZ Fong CKY, et al. Detection of viral genomes in cultured cells and paraffin embedded tissue sections using Biotin-labelled hybridisation probes. Virology 1983; 126: 32-50.

14 Jones DB, Mayberry JF, Rhodes J, Munro J. Preliminary report of an association between measles virus and achalasia. f Clin Pathol 1983; 36: 655-7. 